\title{
Sources of Brand Benefits in Manufacturer-Reseller B2B Relationships
}

Accepted for Special Issue on Branding in Business Markets

Journal of Business and Industrial Marketing (2007)

\author{
Mark S. Glynn, AUT University \\ Judy Motion, University of Waikato \\ Roderick J. Brodie, University of Auckland
}

August 2006

CORRESPONDING AUTHOR:

Mark S. Glynn,

Faculty of Business

AUT University,

Private Bag 92006,

Auckland, New Zealand.

Email: mark.glynn@aut.ac.nz 


\title{
Sources of Brand Benefits in Manufacturer-Reseller B2B Relationships
}

\author{
Abstract \\ Purpose: To develop a conceptual framework that explores the sources of manufacturer brand \\ benefits for resellers. \\ Methodology/Approach: We report a qualitative investigation where packaged goods \\ resellers were interviewed about the benefits of manufacturer brands for their businesses. The \\ qualitative data is analysed to develop several research propositions about the role of brands in \\ reseller B2B relationships.
}

Findings: A conceptual framework is developed that shows manufacturers' brands provide financial, customer and managerial benefits for resellers. These benefits have an impact on reseller relationship outcomes with the manufacturer's brand, which include satisfaction, commitment, trust, dependence and cooperation.

Practical Implications: The conceptual framework provides a model that manufacturers of both major and minor brands can use to understand and manage these brand benefits in order to enhance the relationship outcomes with resellers.

Originality/Value of paper: The paper responds to a need for empirical research to understand the role that brands play in channel relationships (Webster, 2000). It presents a conceptual framework that links manufacturer brand benefits to reseller relationship outcomes. The framework also includes major and minor brands as moderating variables and thus provides a basis for further quantitative research.

Keywords: Brands, Resellers, Business-to-Business Relationships, Qualitative Analysis. Paper Type: Research paper. 


\section{Introduction}

There are many similarities between industrial purchasing and reseller purchasing (buying by retailers and wholesalers), because in both cases purchases are influenced by organisational purchasing policy. Also the magnitude of purchases for both industrial buyers and resellers is large, which results in considerable buying power. In recent years the buying power of resellers has increased (Bloom and Perry, 2001) which has reduced the leverage of the manufacturer's brand with resellers (Shocker et al., 1994). The challenge for manufacturers is to counter this reseller power by differentiating their brands and developing relationships with resellers (de Chernatony and McDonald, 1998). However the role of manufacturer's brands for

resellers is not well understood in the business-to-business (B2B) context, because of the “mistaken assumption” (Webster, 2000 p. 17) that brands are relevant only to consumer relationships and not reseller relationships.

This article responds to Webster's (2000) challenge to better articulate how a manufacturer's brand can provide benefits for resellers within a B2B relationship where end-customers are concerned. In this introductory section, we review the literature on reseller purchasing and B2B relationships within channels. In the following sections we outline the research approach, develop a conceptual model and research propositions. Finally the managerial implications of the research are discussed and conclusions drawn.

Within the industrial marketing literature, research initially established whether brands were important in industrial purchasing (Gordon et al., 1993). As with consumer marketing (Keller, 2003), the focus has been on the brand attributes and implications for brand management. Research about the industrial buyer has identified attributes such as "greater confidence in the 
purchase decision”, “enhanced corporate reputation”, and "increased competitive advantage” (Hutton, 1997; Michell et al., 2001).

However there are some important differences between reseller purchasing compared to industrial purchasing. With industrial buying a brand purchase becomes part of the organisation's production process, whereas resellers purchase brands for immediate resale. Reseller purchasing not only involves organisational considerations, but also a recognition of the end-customers' needs (Fairhurst and Fiorito, 1990). Reseller buying of brands is also more likely to directly affect the reseller organisation's competitive advantage, market and financial performance (Buchanan, 1992). In addition, because of the size and buying power of many resellers, a reseller's performance can affect a manufacturer's success in the marketplace. A further difference between industrial purchasers and resellers is the ability of manufacturers to implement end-customer marketing strategies through resellers (Beverland, 2005; Murry and Heide, 1998). But as Ghosh et al., (1995) note, a manufacturer's ability to use end-customer marketing tools through resellers, such as sampling and point of purchase displays, often requires reseller cooperation.

A poorly managed reseller relationship can undermine the value of a manufacturer's brand (Lassar and Kerr, 1996). For example, a reseller's decision such as the display of a brand in store may affect a manufacturer's brand equity (Buchanan et al., 1999). Furthermore, a reseller could introduce a private label brand to compete alongside the manufacturer's brand (Quelch and Harding, 1996). With industrial brand research, the focus has also been on the purchase of a single brand (Rosenbröijer, 2001). But, as Nevin (1995) points out, resellers also purchase competitors’ brands for resale within a category. 
In much of the retail buying literature the brand is often indirectly assessed using surrogate measures such as product uniqueness and product quality. The few studies that directly consider brand effects have produced mixed findings. Rao and McLaughlin (1989) found that branding was just one of several factors affecting retailer buyer attitudes. Collins-Dodd and Louviere (1999) showed that brand equity influenced a reseller's acceptance of a brand extension, but did not affect pricing or promotion decisions. Baldauf et al., (2003) in their study of tile resellers found that brand equity (awareness, quality and loyalty) explained some of the variance in brand performance perceptions, but also showed that factors such as price, competition and expenses were important as well.

These studies, however, have not addressed the impact of a brand's market share on reseller brand buying. Anselmi (2000) showed that the relative market share of a brand did have an effect on the long-term relationship with distributors and could influence manufacturer advertising allocation decisions. Major brands are also less price elastic (Bolton, 1989) but minor brands benefit more from trade promotions (Hoch and Deighton, 1989). Resellers tend to pass on to their customers a greater proportion of manufacturer promotional allowances for major brands compared to minor brands (Blattberg et al., 1995).

The value of a brand to the end-customer is a joint result of manufacturer and reseller decisionmaking (Anderson and Narus, 1999) and is best optimised through a partnership. Resellers and manufacturers seek channel partners with strong market power to achieve their respective strategic goals (Kasulis et al., 1999). Resellers endeavour to maintain profitability in the face of consumer demand for better value through larger ranges, larger store formats, competitive pricing and private label brands. However, the reality of retailing is that it involves a network of manufacturers, resellers and end-customers (Anderson et al., 1994). Thus, resellers deal 
with many manufacturers and these manufacturers also supply a reseller's competitors (Holmström, 1997). Within the network, the brand is a resource tie that links manufacturers and resellers together to serve the end-customer (Ford et al., 1998). Anderson and Narus (1999) coined the term "marketplace equity" to describe how these resource ties (brand, channel and reseller equity) link manufacturers, resellers and end-customers together.

The resource-based view of the firm (RBV) is a theoretical framework that underlies these ideas about marketplace equity and inter-organisational relationships (Srivastava et al., 2001). Within the RBV, brands are intangible or market-based assets that create competitive advantage for firms. Market-based assets enable firms to create shareholder value from interactions with organisations or entities that it does not control, such as end-customers and channels. Relational market-based assets are relationships associated with external processes such as supply chain management and customer relationship management.

Research has highlighted the importance of external relationship outcomes such as cooperation (Jap, 1999), satisfaction (Cannon and Perreault, 1999), commitment (Ganesan, 1994) and trust (Hoyt and Huq, 2000). However, this research does not include the brand as a resource within these external relationships. To optimise resources such as brands within B2B external relationships, manufacturers need to be aware of the governance mechanisms at work (Heide, 1994). Ghosh and John (1999) identified the impact of governance types and firm resources, including brand equity, on the outcomes of a business relationship. They showed that resources such as brand equity have a different impact on firm performance, depending on the governance strategy that is used. Firms with brands that have strong brand equity with the endcustomer can better use market governance. However, it may be more advantageous for firms with minor brands to use relational governance and form partnerships with resellers. Combs 
and Ketchen (1999) confirmed this point when they found that restaurant chains with a lower brand name reputation were more likely to engage in inter-organisational cooperation as these chains had fewer resources.

While research now recognises the importance of branding in business-to-business marketing, there is still an assumption of a single-stage linkage from the manufacturer's brand to the endcustomer. Brodie et al., (2002) noted that research has not addressed brands as sources of value in inter-organisational relationships. Many brand researchers regard the role of resellers as being one of support (Keller and Lehmann, 2002), with little recognition being given to the cooperative and partnership aspects of manufacturer-reseller relationships. Consequently the effect of these aspects on reseller attitudes and behaviours towards manufacturer's brands is unknown.

This review of the literature leads to three research questions:

1. What are the benefits of manufacturer brands for resellers?

2. What are the important reseller relationship outcomes from manufacturer's brands?

3. How do manufacturer brand benefits influence relationship outcomes for resellers?

\section{Research Method}

The research context to investigate these questions was the B2B relationship between brand manufacturers and retailers. The New Zealand packaged goods retail sector was selected as the relevant population where these established B2B relationships could be studied (Beverland and Lockshin, 2005). Packaged goods brands have also been the focus of much branding research (Grime et al., 2002) and are theoretically relevant to the research problem (Yin, 1994). To ensure that the findings were not limited to a particular group of resellers, a cross-section of participants from the grocery and liquor retailing sectors were selected, following the approach 
of Manning et al., (1998). Key reseller informants consisting of retail buyers and store managers were sampled because they had more frequent interaction with manufacturers. These individuals were not only knowledgeable about brands in retail channels; they also provided richer perspectives from different organisational levels e.g. a store manager vs. a merchandise manager from head office. This selection of informants ensured that "maximum variation" was obtained (Yin, 1994). Care was also taken to interview personnel from competing retailers e.g. Foodtown and New World compared to Pak’n Save which was a limited service, everyday low price retailer as well as from different liquor retailers. Table 1 depicts the participants, their job titles and the reseller trading characteristics.

Take in Table 1.

In-depth interviewing was chosen because it allowed the impact of manufacturer's brands to be explored in terms of the reseller's channel experience. A semi-structured interview protocol was used, consisting of pre-determined open-ended questions. The reseller informants were asked to discuss the activities and issues for manufacturer brands in terms of their business operation. Resellers then commented on their relationships with manufacturers on matters concerning brands and were asked to explain and interpret the possible influences on these relationships. The interview protocol is presented in the appendix.

During May to November 2001, eight reseller informants were interviewed. The interviews were conducted on-site, lasting approximately one to one and half hours, by the same interviewer to reduce bias. Data collection ended when theoretical saturation was reached (Yin, 1994). The interviews were then transcribed verbatim and the transcripts returned to informants to check the transcription accuracy. In addition, the interviews were also supplemented with information from a trade publication, the Nielsen Information Digest (Nielsen, 2001) which provided the researchers with data on the size of the grocery and liquor 
sectors, store listings and names of key personnel in the industry. This publication also contained an overview of the retail trends in 100 product categories, together with a ranking of each brand within a category.

At the time of the research three major resellers, Foodstuffs, Foodland and Woolworths, dominated grocery retailing in New Zealand. Foodstuffs is a cooperative retail chain consisting of independently owned outlets. The retail chains controlled by Foodstuffs included New World, Pak ' $n$ Save and Four Square. Foodland owned the Foodtown and the Countdown chains and was itself a subsidiary of Foodland Australia. Woolworths controlled the Woolworths and Big Fresh chains and was part of Dairy Farms, a Hong Kong based firm. The liquor industry consisted of two major national retail chains, Liquorland and Liquor King and some smaller chains such as Glengarry. In 2000 the grocery sector turnover for New Zealand was \$US20 billion. Comparable figures for the liquor sector were not available; however there were 668 outlets in liquor retail compared to 2760 grocery retail outlets (Nielsen, 2001).

A thematic approach (Zorn and Ruccio, 1998) was used to code the data and generate meaning. This open coding was independently verified by an expert panel of the principal researcher's academic peers (Strauss and Corbin, 1998). Salient themes were then developed from the identification of key words, phrases and quotes based on the language of the participants. A salient theme had to be recurrent (frequency), occur in at least $75 \%$ of interviews and be relevant to the research questions. The subsequent analysis of the coding was then compared to the literature (dialectical tacking). For example from the literature on sources of power in reseller relationships, important aspects of manufacturer's value for resellers were identified (e.g. Kasulis et al., 1999). The data was then reappraised resulting in the identification of the brand benefits for resellers. 
To ensure the trustworthiness of the data, key interpretive and grounded theory research criteria were applied: credibility, generality, transferability, dependability, confirmability, integrity, understanding and fit (Flint et al., 2002). The following procedures indicate that each of these criteria had been met. First, to ensure credibility and generality, interviews were conducted and audiotaped over a seven-month period, with two researchers giving input into the data analysis. Before the analysis commenced, the principal researcher read a printout of each interview and then developed a thematic coding scheme based on the literature and analytical memos from the interviews. Another coder, an expert colleague of the researcher, verified this coding scheme. Second, to aid transferability, theoretical sampling was used. The sampling from the grocery and liquor sectors ensured the findings were not biased towards one retail sector, type of retailer (full service compared to limited service/low pricing) or a particular level within an organisation. Third, dependability was evident in the consistency of response across both retail sectors and the organisation levels sampled. In addition, the principal researcher conducted all the interviews to maintain this consistency. Fourth, confirmability was verified by checking printouts of the transcriptions against the original audiotapes to ensure the wording and meaning had been accurately transcribed. Where the tape was unclear, the participants were contacted by phone to clarify the relevant section of the transcript. These clarifications were mainly concerned with the brand names and the industry jargon used. The comments of resellers were also checked against the Nielsen Information Digest to identify the market ranking of the brands mentioned. Fifth, integrity was maintained by conducting the interviews in a non-threatening manner and providing informants with an information sheet explaining the purpose of the study. Sixth, the transcripts were then forwarded to each of the participants to confirm the accuracy of the transcription and the correct understanding of their comments. As a further verification check, a report of the findings was sent to each of the participants for further comment. Finally, the fit of the study, 
which reflects whether the findings match the area under investigation, was addressed through the steps taken to establish credibility, dependability and confirmability (Flint et al., 2002).

\section{Findings}

This section presents the findings for the three research questions. The financial and nonfinancial benefits are identified followed by the key relationship outcomes for manufacturer's brands. These relationship outcomes are satisfaction, commitment, trust, dependence and cooperation. Finally, how these sources of brand benefits affect reseller outcomes is discussed.

\section{Financial Benefits of Brands}

The first theme reflected the financial outcomes from selling a manufacturer's brand and participants commented on profit margins, price reductions and price premiums. Participants considered that the main financial benefit for resellers was to provide a good margin, which is implicit in the manufacturer-reseller trading relationship. In a representative example one reseller commented:

It's usually in basic gross margin. The reality is that a brand will not be ranged, where it's only going to sit at number three or number four. If its profitability is not 5\% -10\% more than the number one or number two brand, we have no reason to want to sell a product when number one and number two can offer us the sales. Source: [MM].

This quotation identifies the importance of margins and the link to the brand ranking within the category. The financial benefit of a potential brand was also assessed in relation to the sales volume of the current offerings in the category. Resellers then commented on how pricing affected margins and sales volume.

Resellers reported that low pricing often altered consumer's expectations so that a return to “normal pricing” resulted in decreased sales. One reseller commented:

In the South they got themselves into stupidity pricing with bread for example, in some cases, at 99 cents. We are \$2.49 on promotion for a loaf of bread and you can't get out of negative 
margin. Takes long, long time to get out of it. So before we jump, we are very, very cautious and conscious of what we need to be evaluating. We're the leaders long term. We are protecting brands too in that sense. Source: [SM].

This reseller highlighted the negative financial benefits that can occur for some price reductions and the impact on the reseller's business in the long term. The comment also signalled the potential benefits of responsible reseller pricing for the brand manufacturer. In the packaged goods sector, resellers ultimately determine the retail pricing for consumer brands. In contrast to price reductions, resellers also discussed taking a price premium for a brand.

Premium pricing was associated with higher status brands, minor brands and particular variants in the brand's range. For instance, manufacturer brands could have different price points in the category, depending on the brand's position within the range. Resellers mentioned selling one brand variant at a low price point, while leaving other variants in the range at a premium price point (Bergen et al., 1996).

There are some stronger wine brands you must have, Oyster Bay to a certain extent; Lindauer you must have, but I would rather sell Lindauer Special Reserve or Deutz as they are more profitable overall. Source: [LM].

The reseller benefited first by attracting customers when selling the Lindauer variant at a low price and second having an opportunity to also sell (to these customers) either the Lindauer Special Reserve or Deutz (from the same supplier) at a higher price. A brand's variants could therefore offer resellers a means to improve financial returns, based on a brand's price elasticity of demand.

\section{Customer benefits of brands}


Resellers have to balance the need to optimise profit within the category with satisfying the demands of their customers (Broniarczyk et al., 1998). The next theme reflected reseller comments on the requirement to satisfy the overall demands of their customers and it was frequently mentioned that major brands fulfilled this role for them. Resellers focused on the needs of the customer in this theme, rather than any operational considerations as the following comment showed:

Brands are actually what they [manufacturers] do, whereas we retail. We try to meet the needs of our customers and buy whatever they really want of course. If we're looking at our products, we also look at the total market to see what we're missing out on. We make sure that we've got all the top selling lines, so we don't just look internally at our own range, we look outside and benchmark against other ranges, to make sure we have the top lines. Source: [SM].

This statement emphasised the importance of satisfying customer demand including an assessment of brand availability and how their assortment compared to their competitor's offerings. The next statement reflected the customer expectations that resellers would have a particular brand in their range.

Some brands like vitamins and health supplements, we do quite well in that particular market because our [retail] brand used to appeal to an older shopper but it's now actually a lot wider range of customers so our brand still does quite well with them. Whereas perhaps not with carbonated beverages because these are aimed at a much younger market. It [the category] does not quite fit with our brand as well. It still fits with our brand and its definitely part of our product mix but we might not do quite as well with that particular category. So therefore those brands may not do quite as well. Source: [SC].

This reseller not only commented that the brand assortment reflects the customer profile but also indicates the likely consequences for a brand's performance, both within the retail chain and for the manufacturer. 


\section{Managerial benefits of brands}

Managerial benefits reflected the benefits of manufacturer brands to enhance the operational aspects of the reseller's business, excluding the financial or the reseller's customer benefits. The key themes identified were the manufacturer development within the category, brand support, support of the reseller's promotional programme and other areas of collaboration such as the sharing of manufacturer brand expertise. Resellers regarded manufacturer product development as a long-term benefit:

Frozen foods for many years were in decline because there was no development, no innovation, so the market shrank. Now as soon as suppliers started innovating and bringing new ideas and a lot more support to those categories of frozen foods, the categories started taking off. So I suppose as retailers we don't really drive categories, we sell them and we keep in line with the rest of the market, but it's very difficult for us to innovate. Source: [MM].

Although resellers regarded innovation within the category as beyond their expertise, they were prepared to support the manufacturer's marketing activity. Lack of manufacturer support was also viewed as detrimental in terms of maintaining market size and end-customer demand for the category. Brand advertising was another area that was regarded as being beneficial for resellers.

It's very important to have the right marketing, the right advertising programmes behind it, rather than just price discount and the promotional support behind it; it actually creates awareness and people wanting the product. Source: [SC].

This comment shows that the manufacturer's brand advertising support also had benefits for the reseller in terms of pricing and margins. The brand's marketing mix was perceived as a necessity by resellers who commented that a brand "rarely sells by itself".

You have to have that marketing pull, before it actually sells in the stores. It's actually rare that you can just put something on a shelf and expect it to sell. Customers need to be told about it, they need to be educated, and they need to understand what's sitting on the shelf. Every 
product I can think of that has just sat on the shelf, has gone within three months. So there needs to be some support. Source: [MM].

While this comment highlights the role of manufacturer brand support in terms of the endcustomer's brand knowledge and the consequent benefit for the reseller, it also emphasises other reseller benefits such as improved inventory turnover.

Resellers' store promotional programmes to generate customer traffic were important and manufacturers were expected to contribute to these promotional programmes. This reseller stated the expectations of manufacturer support:

Our in-store promotions, every product would have a promotion at least once or twice a year, that they pay for, that we organise internally. There is also an expectation that Cold Power versus Surf [laundry powder] promotions, for example, should be relative to their market share. Source: [CB].

Resellers considered this type of support from manufacturers was a necessity and that the manufacturer's cooperative advertising payment was tied to the brand's market share. The manufacturer's sales force also provided product assistance in the form of shelf layouts and the sharing of market information. Despite the availability of scanner-based market information for resellers, they often relied on the manufacturer for the interpretation of market trends and also collaborated with manufacturers to optimise store shelf layouts for a brand. One reseller explained the boundaries between manufacturers and resellers this way:

We try to have as much correspondence as possible with suppliers over shelf placement. We don't ever proclaim to be experienced in the category, although we're experts at retailing. The suppliers know far more about the categories and how consumers behave within a category, than we will ever do, so they'd be the experts before we will ever be. However, these are our stores and our objectives become number one, which is a combination of profitability, the 
proprietary brands within the category and our desires for our corporate brand product. Source: [CB].

This comment indicates a reliance on the manufacturer's expertise, but also that resellers use this information in conjunction with their corporate goals as part of their overall decision making.

\section{Reseller Relationship Outcomes}

The following relationship outcomes (Wilson, 1995) were identified in $75 \%$ of the interviews, satisfaction, commitment, trust, dependence and cooperation. Reseller satisfaction with the manufacturer's brand is an important construct in the channels literature (Geyskens et al., 1999) and was a key theme in this study. Coding for this theme reflected the consequences of the reseller relationship with manufacturers in terms of the brand. The coding concentrated on the realised brand benefits and differed from the financial benefits theme which addressed potential margin benefits. One reseller gave this example:

Very small suppliers like Lisa who knew nothing, but was very approachable, learnt very quickly, understood what needed to happen and worked with us. We said to her, we're only putting your product in a couple of stores to see how it goes. And she made sure that it went into those stores, that it was well looked after, that everything that could possibly increase the sales, was done in those stores, so it worked really well. So we put it in more stores, and now she's extremely successful, but she's still only a relatively small business, in a very niche market, but the brands are very good. Source: [MM].

This comment illustrated the manufacturer's efforts to achieve the reseller's satisfaction and how the reseller responded to that input. Thus two aspects of satisfaction were identified, first overall channel sentiment 'how well things were going'; and second references to more tangible measures such as sales. A level of reseller commitment to the brand is also evident here. 
Commitment is the desire of the reseller to continue with the brand as part of its range. The following example illustrated a reseller's commitment when there was a benefit for their business:

Heineken beer is doing a reasonably large promotion with the Tennis Open. We extended that promotion, so guaranteeing Heineken display space in the premium area. Source: [LM].

Here the reseller took advantage of a brand's sponsorship activity. In this instance, the reseller committed space in a key area within the store and secured a benefit for the manufacturer.

Trust in the manufacturer on matters concerning the brand was the next relationship theme. Reseller trust reflects the belief "that its needs will be fulfilled in the future by actions taken by the manufacturer” (Anderson and Weitz, 1992, p.312). Reseller trust focused on the reliability of brand supply as well as fairness and honesty, particularly when manufacturers dealt with competing resellers. One reseller summed up the issue as follows:

You can have a company with a very big brand that you could never imagine ever stepping outside the bounds of a deal or giving this retailer more than that retailer, but God help them if we found out that they did. Source: [CB].

Consistency in trading terms and discounts offered was expected and resellers monitored the promotional programmes of their competitors to ensure that manufacturers were being honest. In terms of supply reliability, "out of stocks” was a concern for resellers, particularly with major brands.

It's important that we have a 100\% distribution and a 100\% supply at all times. Sometimes we don't, for example with a Cadbury product recently and a number of individual variants of a chocolate bar had not been supplied. They happen not to be the biggest sellers but it does create problems in the store, because they start to lose space on shelves and there is a detrimental effect on sales. Source: [SC]. 
If a manufacturer could not maintain supply of a particular brand variant, even a minor line, this affected the reseller's business as well as the brand's presence at point of purchase.

Trust in the manufacturer's brand also highlighted the implicit inter-dependence between manufacturer's and resellers. Dependence has been defined within the literature as the degree of difficulty the reseller would have in replacing the brand with an equivalent. However resellers needed manufacturers to supply more than just the brand. The additional benefits such as category innovation and promotional support were evidence of a broader dependence on the manufacturers' brand:

So we rely heavily on the manufacturer to supply the product, to give us money to do some special prices for the customer, and be able to contribute to our advertising. Source: [SC]. Implementation of pricing deals and the reseller's advertising programme also reflected a high level of supply chain coordination between manufacturers and resellers.

The next theme was cooperation: a coordinated action taken by the firm to achieve mutual outcomes with expected reciprocation over time (Anderson and Narus, 1990). To remain competitive with other resellers and satisfy consumer demand, resellers needed to cooperate with manufacturers to fully utilise the potential benefits that brands offered:

An example of what we're actually doing is working with suppliers in a national promotion compliance programme which goes by category and we give displays, number of displays per unit etc. So working with key brands, the brands actually get their opportunity within our promotional displays in the stores. That means working with suppliers to actually to do that because it's an investment on their side. There is actually a cost [to the reseller] in terms of additional stock, but there is maybe an opportunity for us. Source: [LM].

Resellers were willing to cooperate with brands to build store traffic and sales volume. This comment recognised the manufacturer's brand investment and a need to maintain fairness with 
all brand manufacturers by offering them business opportunities. The desire to maintain satisfactory long-term relationships with brand manufacturers was also evident.

\section{Manufacturers' brand benefits and reseller relationship outcomes}

This section focuses on the third research question which considers how the sources of manufacturers' brand value affected key reseller relationship outcomes. The findings from this research question confirm that both major and minor brands can be influential in manufacturerreseller relationships.

Major brands enabled retailers to fulfil their financial objectives through price reductions that generated sales volume. In contrast, minor brands had to offer a better margin benefit to obtain a store listing and generate better sales value. Reseller commitment to a major brand could also mean offering additional business opportunities to that manufacturer:

Bigger brands are more important to us; therefore we're more likely to give these suppliers prompt appointments and better promotional weeks. Source: [CB].

The next set of manufacturer brand benefits was less tangible and related to developing the product category, the sharing of market intelligence and generally enhancing the reseller's productivity. For instance, organising promotions meant that the reseller needed to cooperate with a manufacturer and commit further resources such as purchasing additional inventory for a store promotion. Customer demand for a brand also helped maintain reseller commitment:

Kim Crawford [brand], an up and coming winemaker, doing exceptionally well and tripling the amount of wine every year. For a place like us, we need to be able to keep up with that. Source: $[\mathrm{GM}]$

In this instance, commitment to the brand also meant ensuring that they did not lose sales to other resellers. In contrast, some resellers were wary of a major brand becoming too dominant, preferring to have more inter-brand competition within a category. Minor brands had a 
valuable role too, as these often provided the variety for customers in the store assortment. A minor brand was often considered a source of countervailing power to the major brand:

To a degree, they are just as important from our point, because they keep the large brands honest. So even though we really want to sell Persil, the Bio brand is just as important in some respects, because he's probably offered us greater profitability. Source: [CB].

This comment reflected the reseller's commitment to the major brand but also highlighted the minor brand's margin advantages for this category. One reseller mentioned giving smaller brands a chance to build their business with their organisation, but also noted that some major brand manufacturers sometimes had a passive attitude to the reseller relationship:

Quite often market leaders sometimes can be complacent. They can assume they're going to get sales without rewarding the customer on prices and various things like that. So we quite often back the second or third tier brand, and bring them up to such a point where they go the extra mile in forming the relationship and doing things for the customer and for the store. Then obviously, they'll reap the benefits from us doing things with them. Source: [SS].

This comment showed how a reseller might view the market leader if there was unsatisfactory manufacturer support. Minor brands can benefit in this situation and the reseller emphasised the need for manufacturer support to provide benefits for their customers. Moreover, this reseller highlights the benefits for the manufacturer because of this cooperation.

These three sources of brand benefits influence relationship outcomes and this theme is echoed in the wider literature e.g. the market-based assets framework (Srivastava et al., 2001) and the governance value analysis of Ghosh and John (1999). Ghosh et al., (2004) also showed that distributors expected financial benefits for their business as well as differentiation benefits, which reflected both end-customer and product aspects in a B2B relationship. In addition, the merchandise buying literature showed a broad link from manufacturer resources to reseller satisfaction (Biong, 1993; Ruekert and Churchill, 1984). 
Resellers assess how well a brand is performing in relation to decisions about their customers, promotional programme and store layout. These decisions often involve a reseller commitment, such as purchasing additional product inventory for a store promotion. Satisfaction with the manufacturer's brand can lead to more reseller trust and commitment towards the brand, creates dependence on the brand and leads to cooperation with the brand manufacturer on matters concerning the brand. Furthermore, manufacturers of minor brands have the opportunity to increase their business with resellers when there is dissatisfaction with the brand leader.

\section{Implications and Conclusions}

The findings lead to a set of propositions outlined below and a conceptual model which is shown in Figure 1. A key finding is that there is a range of benefits manufacturer's brands offer resellers other than the brand name itself. These brand benefits have been depicted in the conceptual framework as antecedent variables. The five propositions related to this framework are now outlined. The first three propositions indicate the types of brand benefit that are relevant for resellers. The fourth proposition shows the impact of these brand benefits on reseller relationship outcomes associated with the brand.

$\mathrm{P}_{1}$ : $\quad$ Reseller relationship outcomes for a manufacturer's brand are optimised when resellers fully utilise the financial benefits associated with that brand such as pricing and margins.

$\mathrm{P}_{2}$ : $\quad$ Reseller relationship outcomes for a manufacturer's brand are optimised when there are high levels of managerial benefits including category development, consumer brand support, support of the reseller's promotions and marketing expertise associated with that brand. 
$\mathrm{P}_{3}$ : $\quad$ Reseller relationship outcomes for a manufacturer's brand are optimised when a reseller successfully meets the end-customer demand associated with that brand.

$\mathrm{P}_{4}$ : $\quad$ Reseller relationship outcomes for a manufacturer's brand are optimised when resellers fully utilise combinations of the financial, managerial and consumer benefits associated with that brand.

As customer considerations were important to resellers, the findings show that brand market share can influence the reseller relationship outcomes. Thus major and minor brands have a role within the manufacturer-reseller relationship and market share has been included in the framework as a moderating variable (Baron and Kenny, 1986).

$\mathrm{P}_{5}$ : A brand's market share will moderate the effect of the manufacturer brand benefits on reseller relationship outcomes.

Take in Figure 1.

\section{Managerial Implications}

To date, the relationship outcomes of manufacturer's brands for resellers have not been fully examined in the literature. A primary contribution of this paper is the identification of a range of benefits that manufacturer brands offer resellers. These benefits involve not only a linkage between manufacturers and resellers, but also include the end-customer who is the focus of both manufacturer brand support and reseller marketing (Webster, 2000). The first brand benefit is financial and while all suppliers potentially offer this benefit, its realisation depends on how well the reseller utilises the pricing and margins associated with the brand. The second brand benefit focuses on how resellers use the manufacturer resources to support the brand to manage their business. Manufacturers provide supporting resources for their brands such as category development, brand advertising, support of the reseller's promotional programme, market information and expertise. The third brand benefit is concerned with the reseller's 
customer and relates to the customer's expectations of the reseller in terms of the assortment and the brands themselves.

Manufacturers are concerned with the strategic value of brands and recognise that good relationships with resellers are necessary in realising the value of the product offering (Narus and Anderson, 1988). The next implication from this study is that these "sources of brand benefits" influence the relationship outcomes for resellers. These brand benefits can enhance a reseller's satisfaction, trust and commitment to the brand. Within this interdependent relationship, resellers also need to cooperate with manufacturers to realise these benefits. By focusing on these brand benefits to resellers, manufacturers can enhance a buyer-seller relationship and use their market-based assets to obtain a competitive advantage.

In terms of the manufacturer-reseller relationship, brands are regarded as market-based assets by resellers. Dyer and Singh (1998) considered that these types of assets can be shared between organisations and create relational rents from relationship specific assets, knowledge sharing, complementary resources and governance. While manufacturer's brands are not idiosyncratic investments (Anderson and Weitz, 1992), they are relationship specific in one sense because resellers cannot suddenly switch from one brand to another because of endcustomer demand. There is also substantial knowledge exchange between manufacturers and resellers of market information and category expertise.

The branding literature traditionally focuses on the building of major brands through marketing communication (Aaker, 1991). This study demonstrates that minor brands are very important to resellers not only in terms of the assortment, but also in countering the strength of major brands within the product category. The findings also show that in the packaged goods sector 
brands are a key part of the B2B relationship between manufacturers and resellers. Moreover, resellers too have an active role in brand management, rather than just being one of passive support.

\section{Directions for Future Research}

The key task for future research is to provide empirical support for the propositions developed in this article. First, the sources of brand benefits need to be measured to allow the relative weighting of these brand benefits to be gauged. Second, the impact of each of these brand benefits on relationship outcomes should be tested within a structural model. Third, the strength of the brand is an important moderating variable within this model. To improve the generalisability of such findings, the framework can be applied to other types of industrial purchasing where brands are the focus of the relationship. One example is where industrial purchasing involves brands that already have a consumer market e.g. office supplies. Another relevant B2B context includes the supply of branded OEM ingredients, products or services to manufacturers. Both of these purchasing decisions involve firms assessing the benefit of manufacturer's resources together with the end-customers' expectations.

\section{Conclusion}

Business-to-business branding research has focused primarily on the industrial buyer but has not considered resellers. This paper has examined what benefits manufacturer brands provide to resellers. These benefits not only reflect a manufacturer's brand name strength with the endcustomer, but also include margins and pricing together with additional manufacturer resources associated with the brand such as advertising, promotional support and category development. The findings showed these brand benefits are valued by resellers and influence several relationship outcomes. This broader perspective of manufacturer brand benefits is consistent 
with the antecedents of relationship outcomes previously established by Biong (1993) and Cannon and Perrault (1999).

An assumption in the literature has been that brand strength automatically leads to "trade leverage” with resellers. This assumption had been previously challenged by both Ghosh and John (1999) and Combs and Ketchen (1999). This research investigated multi-brand purchasing of major and minor brands, unlike previous B2B research which addressed only single brand purchasing decisions. Evidence from this study shows that minor brands can be beneficial in helping resellers manage multi-brand purchasing for a product category.

A conceptual framework and research propositions presented in this paper allow the impact of brands to be empirically tested within reseller B2B relationships. Furthermore, major and minor brands have also been included as moderating variables. Manufacturers should consider how the benefits associated with the brand can better build reseller relationships and thus enhance the standing of their brands with the end-customer. 
Table 1. Details of participants

\begin{tabular}{|c|c|c|c|c|c|c|}
\hline Reseller & Chain(s) & Retail Type & $\begin{array}{l}\text { No. of } \\
\text { stores }\end{array}$ & Trading area & Job Title & $\begin{array}{l}\text { Reseller } \\
\text { Code }\end{array}$ \\
\hline \multirow[t]{3}{*}{$\begin{array}{l}\text { Foodstuffs } \\
\text { Auckland }\end{array}$} & New World & Supermarket & 42 & Auckland & Category buyer & SC \\
\hline & & & & & Manager & SM \\
\hline & Pak’n Save & $\begin{array}{l}\text { Discount } \\
\text { supermarket }\end{array}$ & 19 & Auckland & Store Manager & SS \\
\hline Woolworths & Woolworths & Supermarket & 57 & Nationwide & Retail Director- & $\mathrm{RD}$ \\
\hline \multirow[t]{3}{*}{ Foodland } & Foodtown & Supermarket & 29 & North Island & Category buyer & CB \\
\hline & & & & & Merchandise & \\
\hline & & & & North Island & Manager & MM \\
\hline Liquorland & Liquorland & Liquor & 76 & Nationwide & $\begin{array}{l}\text { Merchandise } \\
\text { Manager }\end{array}$ & LM \\
\hline $\begin{array}{l}\text { Glengarry } \\
\text { Hancock }\end{array}$ & Glengarry & $\begin{array}{l}\text { Speciality } \\
\text { liquor }\end{array}$ & 12 & $\begin{array}{l}\text { Auckland/ } \\
\text { Wellington }\end{array}$ & Store Manager & GM \\
\hline
\end{tabular}


Figure 1. The Benefits of Manufacturer Brands to Resellers Framework.

Sources of Brand Benefits

Reseller Relationship Outcomes

Financial:

Pricing

Margins

Customer:

Assortment

Brand expectations

Managerial:

Category development

Consumer brand support

Reseller promotion support

Manufacturer brand expertise

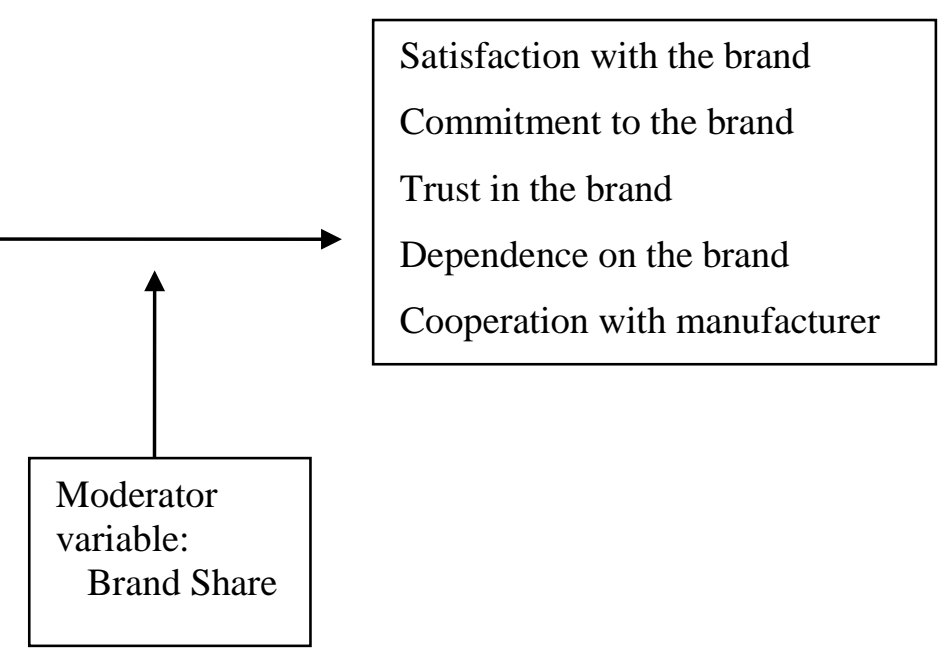


Appendix A.

\section{Interview Protocol.}

Questions:

1. What product categories are you responsible for? Tell me a little about your experiences with manufacturer brands?

2. Within these categories what benefits do you think manufacturer brands have?

3. What aspects of manufacturer brands are important to you? Do you think there is a difference between your company and manufacturers in emphasis on what is important as far as brands are concerned?

4. How would you describe the business relationship your firm has with brand manufacturers?

5. What aspects of this relationship are important? Can you give me any examples?

6. In what ways do brands influence this relationship?

7. What aspects of this relationship do you think may have enhanced manufacturer brands? Please describe some instances where this may have happened.

8. Are there aspects of this relationship that may have harmed manufacturer brands? Can you again describe some instances?

9. Thinking about other competing brands in the product categories you are involved with, how do they influence the relationship you have with a particular manufacturer?

10. How important are manufacturers' brands in helping you meet the corporate goals?

11. How important is the brand's relationship with your customers?

12. To what extent do you collaborate with manufacturers to enhance your business? 


\section{References}

Aaker, D. A. (1991), Managing Brand Equity: Capitalizing on the Value of a Brand Name. Free Press New York.

Anderson, E. and Weitz, B. (1992), "The use of pledges to build and sustain commitment in distribution channels”, Journal of Marketing Research, Vol. 29 No. 1, pp. 18-34.

Anderson, J. C., Håkansson, H. and Johanson, J. (1994), "Dyadic business relationships within a business network context”, Journal of Marketing, Vol. 58 No. 4, pp. 1-15.

Anderson, J. C. and Narus, J. A. (1990), “A model of distributor firm and manufacturer firm working partnerships”, Journal of Marketing, Vol. 54 No. 1, pp. 42-58.

Anderson, J. C. and Narus, J. A. (1999), Business Market Management: Understanding, Creating and Delivering Value. Prentice Hall, Upper Saddle River, NJ.

Anselmi, K. (2000), “A brand's advertising and promotion allocation strategy: the role of the manufacturer's relationship with distributors as moderated by relative market share", Journal of Business Research, Vol. 48 No. 2, pp. 113-22.

Baron, R. M. and Kenny, D A. (1986), "The moderator-mediator variable distinction in social psychological research: conceptual, strategic, and statistical considerations”, Journal of Personality and Social psychology, Vol. 51 No. 6, pp. 1173-82.

Baldauf, A., Cravens, K. S. and Binder, G. (2003), "Performance consequences of brand equity management: evidence from organizations in the value chain”, Journal of Product and Brand Management, Vol. 12 No. 4, pp. 220-36.

Bergen, M., Dutta, S. and Shugan, S. (1996), “Branded variants: a retail perspective”, Journal of Marketing Research, Vol. 33 No. 1, pp. 9-19.

Beverland, M. and Lockshin, L. (2003), “A longitudinal study of customers' desired value change in business-to-business markets”, Industrial Marketing Management, Vol. 32 No. 8, pp. 653-66.

Beverland, M. (2005), “Creating value for channel partners: the Cervena case”, Journal of Business \& Industrial Marketing, Vol. 20 No. 3, pp. 127 -35.

Biong, H. (1993), "Satisfaction and loyalty to suppliers within the grocery trade", European Journal of Marketing, Vol. 27 No. 7, pp. 31-38.

Blattberg, R. C. and Wisniewski, K. J. (1989), "Price-induced patterns of competition”, Marketing Science, Vol. 8 No. 4, pp. 291-309.

Bloom, P. N. and Perry, V. G. (2001), "Retailer power and supplier welfare: the case of Wal-mart". Journal of Retailing, Vol. 77 No. 3, pp. 379-396.

Bolton, R. N. (1989), "The relationship between market characteristics and promotional price elasticities”, Marketing Science, Vol. 8 No. 2, pp. 153-169.

Brodie, R. J., Glynn, M. S. and Van Durme, J. (2002), “Towards a theory of marketplace equity: integrating branding and relationship thinking with financial thinking”, Marketing Theory, Vol. 2 No. 1, pp. 5-28. 
Broniarczyk, S. M., Hoyer, W. D. and McAlister, L. (1998), "Consumers' perceptions of the assortment offered in a grocery category: the impact of item reduction”, Journal of Marketing Research, Vol. 35 No. 2, pp. 166-76.

Buchanan, L. (1992), "Vertical trade relationships: the role of dependence and symmetry in attaining organisational goals”, Journal of Marketing Research, Vol. 29 No.2, pp. 65-75.

Buchanan, L., Simmons C. J. and Bickart, B.A. (1999), "Brand equity dilution: retailer display and context effects”, Journal of Marketing Research, Vol. 36 No. 3, pp. 345-55.

Cannon, J. P. and Perreault, W. D., Jr. (1999), "Buyer-seller relationships in business markets", Journal of Marketing Research, Vol. 36 No. 4, pp. 439-60.

Collins-Dodd, C. and Louviere, J. J. (1999), "Brand equity and retailer acceptance of brand extensions”, Journal of Retailing and Consumer Services, Vol. 6 No. 1, pp. 1-13.

Combs, J. G. and Ketchen, D. J., Jr. (1999), "Explaining inter-firm cooperation and performance: toward a reconciliation of predictions from the resource-based view and organizational economics”, Strategic Management Journal, Vol. 20 No. 9, pp. 867-88.

deChernatony, L. and McDonald, M. (1998), Creating Powerful Brands in Consumer, Service and Industrial Markets (2nd ed.), Butterworth-Heinemann, Oxford.

Dyer, J. H. and Singh, H. (1998), "The relational view: cooperative strategy and sources of interorganizational competitive advantage”, Academy of Management Review, Vol. 23 No. 4, pp. 660-79.

Fairhurst, A. E. and Fiorito, S. S. (1990), “Retail buyers' decision-making process: an investigation of contributing variables”, International Review of Retail Distribution and Consumer Research, Vol 1 No. 1, pp. 87-100.

Flint, D. J., Woodruff, R. B., and Gardial, S. F. (2002), “Exploring the phenomenon of customers' desired value change in a business-to-business context”, Journal of Marketing, Vol. 66 No.4, pp.102-17.

Ford, D., Håkansson, H., Lundgren, A., Snehota, I., Turnbull, P. and Wilson, D. (1998), Managing Business Relationships, Wiley, Chichester.

Ganesan, S. (1994), "Determinants of long-term orientation in buyer-seller relationships", Journal of Marketing, Vol. 58 No. 4, pp. 1-19.

Geyskens, I., Steenkamp, J. B. and Kumar, N. (1999), “A meta-analysis of satisfaction in marketing channel relationships”, Journal of Marketing Research, Vol. 36 No. 2, pp. 223-38.

Ghosh, A K., Chakraborty, G. and Ghosh, D. B. (1995), "Improving brand performance by altering consumers' brand uncertainty”, Journal of Product and Brand Management, Vol. 4, No. 5, pp. $14-20$.

Ghosh, A.K., Joseph, W.B., Gardner J.T. and Thach S.V. (2004), "Understanding industrial distributors' expectations of benefits from relationships with suppliers”, Journal of Business \& Industrial Marketing, Vol. 19, No. 7, pp. 433-43. 
Ghosh, M. and John, G. (1999), “Governance value analysis and marketing strategy”, Journal of Marketing Vol. 63 (Special Issue), pp. 131-45.

Gordon, G. L., Calantone, R. J. and di Benedetto, C. A. (1993), "Brand equity in the business-tobusiness sector: an exploratory study”, Journal of Product and Brand Management, Vol. 2 No. 3, pp. 4-16.

Grime, I., Diamantopoulos, A. and Smith, G. (2002), "Consumer evaluations of extensions and their effects on the core brand: Key issues and research propositions”, European Journal of Marketing, Vol. 36 No. 11, pp. 1415- 38.

Heide, J. B. (1994), “Interorganizational governance in marketing channels”, Journal of Marketing, Vol. 58 No. 1, pp. 71-85.

Hoch, S. J. and Deighton, J. (1989), "Managing what consumers learn from experience”, Journal of Marketing, Vol. 53 No. 2 pp. 1-20

Holmstrom, J. (1997), "Product range management: a case study of supply chain operations in the european grocery industry”, Supply Chain Management, Vol. 2 No. 3, pp. 107-15.

Hoyt, J. and Huq, F. (2000), "From arms-length to collaborative relationships in the supply chain", International Journal of Physical Distribution \& Logistics Management, Vol. 30 No. 9, pp. 750-64.

Hutton, J. G. (1997), “A study of brand equity in an organisational buying context”, Journal of Product and Brand Management, Vol. 6 No. 6, pp. 428-39.

Jap, S. D. (1999), "Pie-expansion efforts: collaboration processes in buyer-supplier relationships". Journal of Marketing Research, Vol. 36 No. 4, pp. 461-75.

Keller, K. L. (2003), Strategic Brand Management: Building, Measuring, and Managing Brand Equity Prentice Hall Inc, Upper Saddle River, NJ.

Keller, K.L. and Lehmann, D.R. (2002), “The brand value chain: linking strategic and financial brand performance”. Working paper, Dartmouth College.

Kasulis, J. J., Morgan, F. W., Griffith, D. E. and Kenderdine, J. M. (1999), "Managing trade promotions in the context of market power”, Journal of the Academy of Marketing Science, Vol. 27 No.3, pp. 320-32.

Lassar, W. M. and Kerr, J. L. (1996), "Strategy and control in supplier-distributor relationships: an agency perspective”, Strategic Management Journal, Vol. 17 No. 8, pp. 613-32.

Manning, K. C., Bearden, W. O. and Rose, R. L. (1998), "Development of a theory of retailer response to manufacturers' everyday low cost programs”, Journal of Retailing, Vol. 74 No. 1, pp. 107-37.

Michell, P., King, J., and Reast, J. (2001), “Brand values related to industrial products”, Industrial Marketing Management, Vol. 30 No. 5, pp. 415-25.

Murry, J. P. and Heide, J. (1998), "Managing promotion program participation within manufacturerretailer relationships”, Journal of Marketing, Vol. 62 No.1, pp. 58-68. 
Narus, J. A. and Anderson, J. C. (1988), "Strengthen distributor performance through channel positioning”, Sloan Management Review, Winter, pp. 31-40.

Nielsen, A. C. (2001), Market Information Digest: A Comprehensive Reference Book on the New Zealand Grocery Industry, A.C. Nielsen New Zealand Ltd, Auckland.

Nevin, J. R. (1995), "Relationship marketing and distribution channels: exploring fundamental issues”, Journal of the Academy of Marketing Science, Vol. 23 No. 4, pp. 327-34.

Quelch, J. A. and Harding, K. (1996), “Brands versus private labels: fighting to win”. Harvard Business Review, Vol. 74 (Jan/Feb), pp. 99-109.

Rao, V. R. and McLaughlin, E. W. (1989), "Modeling the decision to add new products by channel intermediaries”, Journal of Marketing, Vol. 53 No.4, pp. 80-88.

Rosenbröijer, C. (2001), “Industrial brand management: a distributor's perspective in the UK fine-paper industry”, Journal of Product and Brand Management, Vol. 10 No. 1, pp. 7-25.

Ruekert, R. W. and Churchill, G. A. Jr. (1984), "Reliability and validity of alternative measures of channel member satisfaction”, Journal of Marketing Research, Vol. 21 No. 2, pp. 226-33.

Shocker, A.D., Srivastava, R. and Ruekert, R. (1994), "Challenges and opportunities facing brand management: an introduction to the special issue”, Journal of Marketing Research, Vol. 31 No. 2, pp. 149-58.

Srivastava, R. K., Fahey, L. and Christensen, H. K. (2001), "The resource-based view and marketing: the role of market-based assets in gaining competitive advantage”, Journal of Management, Vol. 27 No. 6, pp. 777-802.

Strauss, A. L. and Corbin, J. M. (1998). Basics of Qualitative Research: Techniques and Procedures for Developing Grounded Theory, Sage Publications, Thousand Oaks.

Webster, F. E. (2000), "Understanding the relationships among brands, consumers, and resellers", Journal of the Academy of Marketing Science, Vol. 28 No. 1, pp. 17-23.

Wilson, D. T. (1995), “An integrated model of buyer-seller relationships”, Journal of the Academy of Marketing Science, Vol. 23 No. 4, pp. 334-45.

Yin, R. K. (1994), Case Study Research: Design and Methods Sage, Thousand Oaks, CA.

Zorn, T. E. and Ruccio, S. (1998), "The use of communication to motivate sales teams”, Journal of Business Communication, Vol. 35 No. 4, pp. 468-99. 
Mark S. Glynn is Senior Lecturer Marketing and Advertising in the Faculty of Business at AUT University, Auckland, New Zealand. He obtained his $\mathrm{PhD}$ in marketing from the University of Auckland and was the winner of the 2006 Emerald/EFMD Outstanding Doctoral Research Award in the category of Marketing Strategy. His research experience is in the areas of branding, business to business marketing and retail channels. His research has been published in journals including the Journal of Product and Brand Management and Marketing Theory. He is on the Editorial Board of Industrial Marketing Management.

Judy Motion is Professor of Communication at the University of Waikato Management School, New Zealand. She researches marketing, management and public policy issues drawing upon qualitative approaches to theorize discourse practices. Judy leads a government funded research programme investigating sustainable biotechnology. She is the Australasian associate editor of the Journal of Communication Management and Corporate Communications: An International Journal, and a member of the editorial boards of the Journal of Public Affairs, the Australian Journal of Communication and PRism. Her research is published in numerous journals including Public Relations Review, Media Culture \& Society, Journal of Communication Management, Politic al Communication, European Journal of Marketing, the Australian Journal of Communication and the Journal of Public Relations Research.

Roderick J. Brodie is Associate Dean (Academic) and Professor in the Department of Marketing at the University of Auckland of Business School, New Zealand. His research experience is in the areas of marketing strategy, branding, marketing research, services, marketing science and forecasting. His publications have appeared in international journals including Journal of Marketing, Journal of Marketing Research, International Journal of Research in Marketing, Management Science, and Journal of Services Research. He is an area editor of Marketing Theory and on the Editorial Boards of the Journal of Marketing, the International Journal of Research in Marketing, the Journal of Service Research, and the Australasian Journal of Marketing. 